\title{
Wandering of Mass Reproduction of Harmful Insects Within the Natural Habitat
}

S. V. Stankevych1 ORCID: https://orcid.org/0000-0002-8300-2591.

H. V. Baidyk1 ORCID: https://orcid.org/0000-0002-2229-4498.

I. P. Lezhenina1 ORCID: https://orcid.org/0000-0001-6510-4781.

M. O. Filatov' ${ }^{1}$ ORCID: https://orcid.org/0000-0003-2357-1853.

V.I. Martynenko1 ORCID: https://orcid.org/0000-0001-6730-9502.

V.I. D'yakonov' ${ }^{1}$ ORCID: https://orcid.org/0000-0001-5149-685X.

I. V. Nepran1 ORCID: https://orcid.or/0000-0001-8194-6065.

V. O. Mykhailenko ${ }^{1}$ ORCID: https://orcid.or/0000-0001-8281-2835.

D. V. Havva1 ORCID: https://orcid.or/0000-0001-6516-7846.

S. V. Bondarenko1 ORCID: https://orcid.org/0000-0002-8685-5928.

K. B. Novosad1 ORCID: https://orcid.org/0000-0003-2043-9160.

L. P. Kava2 ORCID: https://orcid.or/0000-0001-5757-6738.

R. V. Yakovlev² ORCID: https://orcid.or/0000-0003-4364-3308.

L. V. Nemerytska3 ORCID: https://orcid.or/0000-0001-7933-0587.

L. V. Golovan'1 ORCID: https://orcid.org/0000-0002-7630-3222.

I. V. Klymenko4 ORCID: https://orcid.org/0000-0002-3014-1694.

IV.V. Dokuchaev Kharkiv National Agrarian University, v. Dokuchaevske, Kharkiv region, 62483, Ukraine

${ }^{2}$ National University of Life and Environmental Sciences of Ukraine, Kyiv, 03041, Ukraine

3 Zhytomyr Agricultural College, Zhytomyr, 10031, Ukraine

V. Ya. Yuryev The Plant Production Institute of NAAS, Kharkiv, 61060, Ukraine

E-mail: sergejstankevich1986@gmail.com. Tel.: +38-050-4000-985.

Received: 12.11.2019. Accepted: 11.12.2019

The wandering of non-linear systems along the field of the possible development paths is one of the important characteristics of dynamic non-linear systems in synergetics. Insect populations are a complex of open biological systems with chaotic non-linear dynamics in space and time. Predicting their future development is not an easy task. Ignorance of the non-linear systems dynamics regularity is the cause of the repeated errors in predicting and, as a result, "sudden" appearances of "unexpected" and unpredictable mass reproductions of short-horned grasshoppers and locusts, winter moth, webworm beetle, sun pest and some other insect pests, the consequences of that are catastrophic for agriculture and forestry. In this article the authors analysed thoroughly the chronicles of the mass reproduction (wandering within the temporal and spatial limits of the natural habitat) of such species as short-horned grasshoppers and locusts, webworm beetle and sun pest. These pests have been known to mankind since time immemorial and they are extremely devastating.

Key words: Insects; Pests; Mass reproduction; Wandering; Natural habitat; Population dynamics; Polycyclic character; Synchronism; Non-linearity

\section{Introduction}

The wandering of non-linear systems along the field of the possible development paths is one of the important characteristics of dynamic non-linear systems in synergetics. At the same time the non-linear system "non-rigidly" follows the "prescription" and makes a sort of wandering along the field of the possible development paths in accordance with the non-linear dynamics in the real nature of our random being (stochastism and determinism (Kniazeva, Kurdiumov, 2002). This theoretical position of non-linear dynamics is important for the theory and practice of harmful insect population ecology, in the first turn it is necessary for establishing the migration of their mass reproduction primary breeding grounds as the prognostication of the aggravated regimes (the beginning of mass reproduction in space), predicting and making decisions (management) in plant protection. It must be assumed that ignorance of these regularities of the non-linear systems dynamics was the cause of the repeated errors in predicting and "sudden" appearance of "unexpected" and unpredictable mass reproductions of short-horned grasshoppers and locusts, winter moth, webworm beetle, sun pest and some other insect pests. 
Predicting the future from the standpoint of synergetics proved to be more difficult task than it was previously thought by the representatives of classical science. It turned out that in principle it is impossible to give a long-term prognosis of the meteorological, chemical and ecological systems behavior (Malinetskii, 1997; Moiseiev, 2001; Nicholas, Prigozhin, 2003).

Over the past 30 years it has been shown that there is another important class of objects. Formally they are deterministic, and knowing exactly their current state it is possible to establish what will happen to the system in any distant future. But at the same time it is possible to predict its behavior only for a limited period of time. Even small inaccuracy in the value of the initial state of the system grows in due course, and from some time we lose the ability to predict anything. During this period the system has the chaotic state (Malinetskii, 1997). It is obviously that such a pattern is also characteristic for the vast majority of the insect pests, which mass reproduction is still impossible to predict for a long period of time due to the inaccuracy of the primary quantitative and qualitative data and their chaotic dynamics of numbers and non-linearity. Very little is known about the properties of the non-linear world. One of the greatest ideas of the non-linear world is that of the solutions ramification or bifurcations. Bifurcation is a change in the number or stability of a certain type of solutions (Malinetskii, 1997), and it is the ramification point of the possible evolutionary paths. Therefore taking into account the complexity of the non-linear systems dynamics (in our case the insect populations) perhaps we should rely on the qualitative prognoses like: when we should expect the regular mass reproduction of one or another insect in the scope of this or that year.

\section{Materials and Methods}

The purpose of the work is an attempt to identify the regularities of the mass reproduction of insects by analyzing the historical data about them, since in recent years the problem of the catastrophic events, or the so-called in synergetics the aggravated regimes in illinear systems, has become quite urgent when one or more quantities that characterize the system eventually have grown up to the infinity. In the ecology of the populations it is the "unexpected" disastrous massive reproductions of insects. By means of conducting the theoretical synthesis of the information about the regularities of the population dynamics of the most widespread insect pests of the agricultural crops, forests and fruit and berries plantations, which is based on the past and the present, the analysis of the contemporary ideas about the dynamics of the insect populations and the theories that explain the seasonal and annual changes in the number of insects has been carried out. When conducting this study in order to reveal the primary centres of the mass reproductions we have analysed various sources of scientific literature as for the massive breeding of the main pests of the agricultural crops and forest plantations. We think, it is possible to note certain regularities in the cyclic character and synchronousness of the mass reproductions of the most important pests of the agricultural crops and forest plantations with the aim to improve the prediction as for the beginning of the next mass reproductions and to find out the regions in which their occurrence is possible.

\section{Results and Discussion}

\section{Short-horned grasshoppers and locusts (mass reproduction in space and time)}

The mass reproduction of short-horned grasshoppers and locusts has been known to mankind since the onset of agriculture and plant growing. We have done a retrospective analysis of their mass reproduction based on the information presented in the scientific literature (Figuier, 1869; Keppen, 1870; Kulagin, 1921; Kripiakevich, 1927; Borisenkov. 1988; Barash, 1989; Yavornytskyi, 1990; Sergeiev, 2007; Sergeiev, 2010; Biletskyi, 2011).

The first mass reproduction of the short-horned grasshoppers and locusts in the history was noted in 1490 BC. In 1104 BC the short-horned grasshoppers and locusts flew upon Libya. In 904 BC they devastated Palestine; in 104 BC these pests devastated some regions of the Chinese Empire, when due to the crop failure and famine caused by the locust invasion the campaign of the Emperor Wang Ti against the Tavans did not take place.

In 203 and $172 \mathrm{BC}$ the Italian locust completely destroyed all the crops in the southern Italy.

In $63 \mathrm{AD}$ the Parthian king Vologezez was forced to raise the siege of the Armenian fortress Tigranocerta because the locust completely destroyed all the grasses, leaving his cavalry without forage.

In the 4th century AD Saint Jerome mentioned the catastrophic mass reproduction of the locusts in Palestine.

In 456 in Phrygia (an ancient country in the northwestern part of Asia Minor) the catastrophic reproduction of the desert locusts took place; in 576 it was in Syria and Mesopotamia (one of the oldest centres of civilization); in 580 the mass reproduction of the locusts took place in the same area again; in 592-593 the locusts appeared in Germany on a mass scale; in 677 they were in Syria. In 678-679 the mass reproduction took place in the Chinese empire; in 722 - again in Syria; in 784 in Syria the locusts destroyed all the vegetation and packed all the houses (Keppen, 1870).

In 872-874 the mass reproduction of the locusts took place in Germany and France; in 929 - in Egypt; in 957 - in Syria and Mesopotamia; in 960, 969 and 1002 - in Syria; in 1010 - again in Syria; in 1084 - in Germany, England, France, Poland and Russia; in 1092 the mass reproduction of the locusts took place near Constantinople.

The first mass reproduction of the locusts ("prusi" - Old-Slavonic) was dated in 1008; then in 1094-1095 it was noted in Kiev's Russ; then the mass reproduction of the locusts was noted in the Grand Princedom of Kyiv in 1103, 1195-1196, 1237, 1338-1339, $1401,1408,1472-1475,1501,1527,1534,1541-1542,1546-1549,1583$, and in 1601-1603; then it was noted in Ukraine in 1645$1646,1648-1649,1652,1681,1689-1691,1700-1709,1713,1719-1720,1726,1743,1747-1749,1756-1758,1783,1793,1799-$ 1802 , 1804-1806, 1811-1818, 1820-1829, 1839-1840, 1846-1849, 1851-1852, 1859-1860, 1862-1864, 1866-1869, 1884-1888, $1890-1893,1901-1903,1910-1913,1923-1925,1930-1932,1937-1939,1945-1947,1951-1953$, and in 1995-1997 it was noted in the South of Ukraine, in 2003 the mass reproduction of the locusts was noted in the Autonomous Republic of the Crimea; the density of the larvae was up to 5000 specimens $/ \mathrm{m}^{2}$ ). The mass reproduction of the Italian locusts in the Lower Volga region was noted in 1968-1969, 1972, 1978-1983 (Sergeiev, 2010).

Over the period of 63-2003 the reoccurrence of the mass locust reproduction that occurred in the past amounted to 800 years (1195-1995), 700 years (1237-1937), 500 years (1401-1901), 400 years (1008-1408), 300 years (1389-1689), 200 years (1401$1601), 100$ years (1401-1501), 100 years (1713-1813) and 100 years (1811-1911).

During the given period the catastrophic mass reproduction of the locusts was described in the works of the historians, ecologists, writers and even travelers. In 1649 there was a great crop failure; only the seeds fall of rye gave the yield in the places there the Cossacks were encamped; the spring rye was harvested by hand. The same year there was a terrible amount of the locusts that ate the cereals; and there was also a great number of mice; no one could remember that there had been so many mice earlier; so there was a high cost of bread, salt and hay "(Yavornytskyi, 1990). 
"In the year of 1583 the locusts rampaged in the Zaporozhian steppes; Samiilo Zborovskyi, the owner of the Zolochev town of Lviv District, who at this time was sailing with a detachment of the Polish gentry along the Dnipro to connect with the Zaporozhian Cossacks for a joint campaign against the Tsar Ivan the Terrible of Moscow, met a cloud of the locusts below the Khortytsia Island on the Dnipro that caused the death of 300 horses and a lot of horses became swollen" (Yavornytskyi, 1990).

"The year 1647 was unusual as numerous signs in the heaven and on the earth threatened with the unknown disasters and unprecedented events. The chronicles of that time informed that in the spring, having hatched in an unprecedented great number from the Wild Field, the locusts had eaten the crops and grasses, and this fact betokened the Tatar raids ... "(Senkevich, 1983).

"In 1709 the locusts stopped the army of Charles XII, the King of Sweden, retreating to Bessarabia after the Poltava defeat. The king thought it was the hail as the locust hit his army very heavily. The men and horses were blinded by this living hail falling from the cloud that darkened the sunlight. All the villages laying on its way were ruined. The same year a significant part of Europe was devastated by it" (Figuier, 1869). "In 1735 the clouds of the locusts darkened the sunlight and moonlight for the Chinese. Not only the standing crops but even the grain stored in the shops, even the clothes in the houses were devoured by these insects "(Figuier, 1869). "In 1739 the locusts covered the entire surface of the soil from Tangor to Mogador (Moroccan Empire). The entire area adjacent to the Sahara was devastated while on the other side of the El-Kos River not a single insect was seen" (Figuier, 1869). According to the chronicles the mass reproduction of the locusts also took place in the Middle Ages; later the literary sources recorded the numerous outbreaks of their numbers during the $19^{\text {th }}$ and $20^{\text {th }}$ centuries when there were more than 84 outbreaks of these insects. Judging by the information (Sergeiev, 2007) the mass reproductions in the territory of the former USSR not only reduced but, on the contrary, sharply reinforced with a significant increase in the treated areas. Thus in 200010 million hectares including 8 million hectares in Kazakhstan and 2 million hectares in Russia were treated to control the locusts. In 1989 and 1996 , that is only two times, the treated areas were a little more than 4 million hectares.

In 1999 during the catastrophic mass reproduction of the locusts in Kazakhstan they destroyed 220 thousand hectares of cereals, and the losses amounted to 15 million US dollars; at the same time the costs for the locust control amounted to \$ 4,8 million in 1999, and in 2000 the costs were \$23 million. Further examples are given according to M.G. Sergeiev and A.V. Lachinskii (Sergeiev, 2007). In 1992 in the Lower Volga Region and Western Kazakhstan the areas of the Italian locust population gradually expanded to the east, in Kyrgyzstan only from 1997 to 2000 their number increased by 7 times. In the south of Western Siberia a sharp increase in the number of these pests began in 1999, and the outbreak reached its maximum in 2000 . The above-mentioned authors believe that this fact was facilitated by weather conditions.

A great number of the Italian locust was not only in the Western Kazakhstan, the Lower Volga Region and Ciscaucasus, but also in Ukraine (the southern steppe regions and the Autonomous Republic of Crimea). The mass reproduction of the Italian locust was noted in 2005-2006 in France. At the end of the XX and the beginning of the XXI centuries the large flocks of the migratory locusts (Locusta migratoria L.) were recorded in some regions of the European part of Russia, in the south of Siberia, in Central Asia and in the East Kazakhstan. After a long depression (since 1992) another mass reproduction of the desert locust (Schistocerca gregaria Forsk) began in West Africa in October. In September 2000 the locusts spread over 15 countries of West and North Africa and populated the huge territories. We predicted the beginning of this mass reproduction of the desert locusts back in 1996 (Zachary, 1996). This outbreak occurred in 2003-2005 and caused the monetary damage of \$ 1 billion; only in 2003-2005 13 million hectares were treated to control the desert locusts in 22 countries on three continents (Lachinskii, 2001).

In the south of Africa in 1995-1996 the local species of brown locust Locusta pardalina Walk (kindred to the migratory locusts) propagated on a mass scale. At that time the costs for its controlling amounted to about $\$ 3,5$ million.

In 2004 another outbreak in the number of the migratory locusts was recorded in China on the border with Kazakhstan, Russia and Mongolia. In 2004-2005 in Australia there was one of the greatest mass reproductions of the Australian gregarious locust (Chorthoicetes terminifera Walk) over the last decades. At the same time about 450 thousand hectares were treated.

In 1999-2001, 2004 and 2006 the powerful outbreaks in the number of this pest were recorded in the southwestern Australia, where the mass locust reproduction occurs not often (Sergeiev, 2007).

\section{Mass reproduction of webworm beetle}

A webworm beetle is one of the most common pests of many agricultural and wild growing plants. It is known that its natural habitat includes 14 countries of the Old and New Worlds and, according to the calculations, the area of this territory is about 11,552 million $\mathrm{km}^{2}$ while the area of Ukraine does not exceed 5,2\% of this territory (Kravchenko, 2002). This fact is a real limitation for the regional forecasting of the locusts mass reproduction, especially when using the solar activity as a predictor expressed in terms of the relative Wolf's numbers $(\mathrm{W})$.

The first known mass reproduction of the webworm beetle in the Principality of Kyiv was in 1680 . "In 1680 in Ukraine there was a torrid sun heat and aridity; all the water and grasses dried out; the worms propagated and ate the beans, cabbage, peas, hemp and buckwheat and passed from one field to another" (Yavornytskyi, 1990). The second mass reproduction took place in 1686. "The same year everything was black with the worms which were the caterpillars' height; they caused a great damage to the hemps and to other potion, but intentionally did no harm. The flocks of them went along the road to the town and through the gateway; from the town the flocks went to the gardens without fear of the rains, though the summer was wet" (the Chronicle of Eye-Witness, 1878). The mass reproduction of the webworm beetle in our country was first noted by the famous academician and traveler Peter Simon Pallas (1743-1811) on May 12, 1763 when he saw the flying butterflies in huge numbers near Saratov; there were so many of them that they looked like "the gnats in a young oak grove" (Rossikov, 1903).

Eversmann classified the webworm beetle as a harmful insect in the broad sense of the word, indicating that the latter appeared annually in the southwestern foothills of the Urals and the adjacent steppes, and its caterpillars caused the great damage to the vegetation there (Rossikov, 1903).

According to S.M. Mokrzhetskii (Mokrzhetskii, 1902) the webworm beetle caused the great damage in the United States of North America at one time. F.B. Paddock in his article "The sugar-beet web worm" published in the journal "Economic Entomology" in December 1912 reported that in 1909-1910 the beet plantations in America suffered heavily from the webworm beetle; from 35 to $55 \%$ of all the cultivated beets were lost and the losses amounted to 2-5 percent of the sugar content. Paddock believed that the webworm beetle had appeared on the Pacific coast and then spread to the states of Colorado and Nebraska in 1869, and the harm from it became apparent after many years of its first appearance in America.

The wandering of the mass reproduction breeding grounds within the natural habitat is most clearly manifested in the case of the webworm beetle. Thus in 1769 such breeding grounds were near Syzran (The Volga region); 100 years later in 1869 they were noted in the Kyiv and Podolsk provinces; in another 100 years, in 1969, the mass reproduction breeding grounds were noted in the North Caucasus and in 1869 - in the USA. 
In 1853 the initial breeding ground appeared in the Veliko-Anadolsk Forestry (the southeastern part of the Yekaterinoslav province and in the Krasnoyarsk District (Dobretsov, 1980). In 1854 it moved to the Sarepta (the Volga Region) where its caterpillars completely destroyed all the plants except the cereals across the territory of 200 versts. In 1854-1855 the caterpillars damaged the vegetable crops in some regions of the Kharkiv province (Keppen, 1870), and already in 1855 the webworm beetle propagated on a mass scale in all regions of the southern Russia, in the Volga Region, in Siberia and Ukraine. The separate breeding grounds with a high density of caterpillars of the webworm beetle cyclically arose in 1864 in the Tauride province; in 1847 they were noted in the Tula region, in 1868-1869 they were in the Kyiv and Poltava provinces, in 1870 there was a great number of them in the vicinity of Astrakhan; in 1873 the breeding grounds occurred in the Don region; in 1880 they were noted in the Kyiv, Yekaterinoslav, Poltava and Kharkiv provinces as well as everywhere in the area of beet-growing; in 1892 they appeared in the Don region (Keppen, 1870). In 1900 the breeding grounds of the webworm beetle occurred in the Kharkiv, Kyiv, Yekaterinoslav, Don, Poltava and Nizhnii Novgorod provinces; in 1901 they occurred over a vast territory from the countries of the Baltic Sea to Kazakhstan and Siberia (Konakov, 1930). In 1902 the separate breeding grounds with a high density of the webworm beetle's caterpillars were recorded in the Kyiv, Voronezh and Kherson provinces and in the Don region; in 1903 they were noted in the Kiev and Kherson provinces, in 1909 they again occurred in the Kyiv and Kherson provinces and in the USA.

In 1912 a catastrophic mass reproduction of the webworm beetle was noted in the territory of several districts of the Astrakhan province; then the beetles destroyed all the vegetation (except the cereals) both wild growing and cultivated one, many garden crops and thus, caused a national disaster (Sakharov, 1923). According to V.G. Averin (Averin, 1913) in 1912 great numbers of the webworm beetles were found on beets, potatoes, clover and beans in Kharkiv, Sumy and Kupiansk districts; and already in 1913 they propagated in the Kharkiv province in an enormous number and caused not less than a million rubles of monetary damage. I.A. Porchinskii (Belskii, 1932) indicated that in 1912 the webworm beetles propagated heavily over a vast area from Central and Western Siberia to the provinces of the South-West Russia. They caused damage to water-melon, melon and gourd plantations, sunflowers, beets and many other crops. In 1915 the beetles propagated in the Astrakhan and Kyiv provinces; in 1915 the webworm beetle propagated in the Voronezh, Don and Orel provinces.

In 1921 the mass reproduction of the webworm beetle was recorded throughout the beet-growing areas, and its appearance was like a national disaster (Lindeman, 1923). In 1922 on the Right Bank of Ukraine, in the region of Smila and even in more southern districts "... it was difficult to find some specimens of butterflies" (Zverozomb-Zubovskyi, 1924), while hundreds of acres of beet crops were again damaged in the Central Chernozem Republic (Konakov, 1930). In addition to the Central Chernozem Region the webworm beetle on a mass scale propagated in the southeastern Poland, throughout the territory of Ukraine; in some regions of the Kyiv, Poltava and Chernihiv regions its caterpillars destroyed from 60 to $100 \%$ of the sugar beet crops (Konakov, 1930). In the Don region the vegetable gardens were completely destroyed in some places; the crops of corn and fodder grasses were also severely damaged at the experimental station (Averin, 1913). In 1929 a catastrophic mass reproduction of the webworm beetle was noted over a vast territory, the northern border of which passed through Tver, Kostroma, Perm, Sverdlovsk, Tara, Tomsk, Krasnoyarsk, Irkutsk and Verkhnedvinsk in the east, in the southeast the border passed through Minusinsk, Semipalatinsk, Akmolinsk, Astrakhan, Kislovodsk, Novorossiisk and the southern coast of the Provish river, in the west it passed through Poland. A great number of the webworm beetle also appeared in Bulgaria, Hungary, Germany, Poland, Romania and Yugoslavia. Was it possible to predict the sudden reproduction of the beetle in 1929? At one time many entomologists and ecologists gave a negative answer to this question. After this huge mass reproduction of the webworm beetle a theoretical concept was developed which explained the conditions for the occurrence of this pest mass reproduction and determined the ways to prevent its harmfulness. I.Ya. Poliakov (Poliakov, 1964) wrote at one time: "If to take into consideration this concept then at present there are no favourable conditions for the mass appearance of the webworm beetle. The increasing intensity of soil cultivation in the agricultural areas and the development of large areas in Kazakhstan, where the reservation and accumulation of the webworm beetle with its subsequent flight to other districts could be possible, prevent from its appearance".

"Probably there is enough reason to consider the webworm beetle a former mass pest despite the fact that not a great number of this species is annually observed in almost all agricultural areas" (Poliakov, 1964). Unfortunately the prognosis of the leading forecaster of the former USSR did not come true! The analysis of the regular mass reproduction, especially global (in 1975 and 1988), indicates that the primary breeding grounds with a high number of this pest made a regular wandering within its natural habitat. According to the data of A.N. Frolov (Frolov, 2011) in 2008 another outbreak of the webworm beetle reproduction first began in the Trans-Baikal Region of the Russian Federation. In 2009 the area infested by the pest continued to grow in the Amur Region. The number of the pest that exceeded the threshold was noted in Buriatiia, Altai and Krasnoyarsk Districts, Irkutsk, Novosibirsk, Kemerovo and Tomsk Regions and in Khakasiia; its appearance was also noted on the Sakhalin Island. In Ukraine the last mass reproduction of the webworm beetle was recorded in 2011-2013. In 2011 the webworm beetle was spread almost everywhere in the southern and eastern regions but in the central regions of Ukraine it was spread locally; the outbreaks of its numbers were also noted here although in 2008-2010 they were not of an economic importance here.

In the "Forecast ... of the Russian Federation for 2010" the information indicates that in 2010 there was the mass of the beetles in the Voronezh Region despite the high temperature and low humidity of the air; the females had a well-developed fat body and the forming, maturing and mature egg production. This statement contradicts both the past and modern ideas of the researchers studying the biology and ecology of the webworm beetle in the zone of its spreading during the mass reproduction and depression! All the researches were unanimous in the fact that high temperatures and droughts were the causes of the pests' infertility.

Triebel S.A., assessing the phytosanitary situation in Ukraine in 2014, clearly indicated that in 2014 the acreage treated with the products controlling the webworm beetle could amount to two and even more million hectares. However the webworm beetle again played the forecasters a trick. Its mass reproduction, which began in Ukraine in 2011, ended in 2013 when 1 million 209 thousand ha were treated against the beetle in the steppe and forest-steppe zones of the republic, i.e. in 2013 there was the peak of this pest number, although this fact was predicted yet in 2014-2015 (Belaiev, 2003).

\section{Wandering of mass reproduction of a sun pest in the natural habitat}

In the European habitat the mass reproduction of the sun pest has been known since the $19^{\text {th }}$ century, in the Asian habitat it has been known since 809. It is known that 1100 years later in 1909 the mass reproduction of the sun pest was recurred in the Krasnodar and Stavropol Districts, in Rostov Region, Iraq, Iran, Syria, Turkey, Tajikistan, Uzbekistan, Ukraine, the Volga Region and in the Central Chernozem Region. As the old residents witnessed in 1909 there was a huge number of the sun pest in the Rostov Region; the local residents plowed the soil in order to destroy the bug's larvae (Peredelskii, 1947). According to V.G. Averin in 1909 the bugs of the sun pest completely destroyed the wheat crops in the Zmiivskyi district of the Kharkiv province (Averin, 1913). In 
1925-1927 the mass reproduction of the sun pest took place in the Luhansk, Odessa and Kharkiv regions. In 1927 the primary breeding grounds of this pest were found in two bordering districts of Turkey; and already in 1928-1929 the bugs populated the greater part of the Kiliiska valley, the granary of Turkey. In 1929 the destruction of wheat and barley due to the damage caused by the sun pest reached the losses estimated at one million German marks (Peredelskii, 1947). According to the legendary data of Nadir Shah Arshar the similar situation was in Iran in 1736-1737 (Peredelskii, 1947). 200 years later beginning from 1937 the regular mass reproduction of this pest began in Iraq, Iran, Jordan, Lebanon, Syria, Palestine, in the Stavropol and Krasnodar Districts, in the Rostov Region, in the Volga steppe zone, in the Central Chernozem Region and in Ukraine. In 1972-1973 the regular mass reproduction of the sun pest took place in the Kharkiv and Kherson regions. It is significant that in 1972 the primary breeding ground with a high density of up to 50 specimens $/ \mathrm{m}^{2}$ first appeared in Velykoburlukskyi district (the ravine forest, Prykolotne village) and then it appeared in the Kharkiv region (in the outlying districts of the habitat) in the village of Communist, the educational and experimental farm of the Kharkiv Agricultural Institute (now the Kharkiv National Agrarian University named after V.V. Dokuchaiev).

\section{Conclusion}

At the example of the mass reproduction of the short-horned grasshoppers and locusts, webworm beetle and sun pest we have shown the regular nature of their wandering and reproduction in space and time, which became understandable due to the achievements of non-linear dynamics. In addition we came to the conclusion that the aggravated regimes and wandering within the habitat of the pests' numbers outbreaks are a fundamental limitation of predicting the populations' dynamics as the complex nonlinear systems.

\section{References}

Averin, V.G. (1915). Obzor vreditelej, nablyudavshihsya v Har'kovskoj gubernii za 1913 god. Otchet entomologicheskogo byuro za 1913 god, Har'kov, 10-65. (in Russian).

Barash, S. I. (1989). Istoriya neurozhaev i pogoda v Evrope po HVI v. n. e., Leningrad, Gidrometeoizdat, 238. (in Russian).

Beleckij, E. N., Stankevich, S. V. (2018). Policiklichnost', sinhronnost' i nelinejnost' populjacionnoj dinamiki nasekomyh i problemy prognozirovanija, Vienna, Premier Publishing s.r.o. Vienna (in Russian).

Beleckij, E. N., Stankevich, S. V., Nemerickaja, L. V. (2017). Sovremennye predstavlenija o dinamike populjacij nasekomyh: proshloe, nastojashhee, budushhee. Sinergeticheskij podhod. Vesti HNAU im. V. V. Dokuchaeva. Series Fitopatologija i jentomologija, 1-2, 22-33. (in Russian).

Beletskij, E. N. (2011). Massovye razmnozheniia nasekomykh. Istoriia, teoriia, prognozirovanie, Kharkov, Maidan, 172 . (in Russian). Bel'skij, B.I. (1932). K voprosu ob ochatah razmnozheniya lugovogo motyl'ka (Loxoslege sticticalis) v stepnoj oblasti Ukrainy. Lugovoj motylek v 1929-30 godah. Sb. mater. i statej po biologii lugovogo motyl'ka i bor'be s nim, Kiev: Izdatel'stvo UNIISa, Kniga 2, 21-36. (in Russian).

Betyaev, S.K. (2003). Prognostika: pervye shagi nauki. Voprosy filosofii, № 4, 3-13. (in Russian).

Bezpal'ko, V.V., Zhukova, L.V., Stankevych, S.V. (2019). Ecologically safe methods for presowing treatment of cereal seeds. Ukrainian Journal of Ecology, 9 (3), 189-197.

Borisenkov, E. P., Paseckij, V. M. (1988). Tysyachiletnyaya letopis' neobychajnyh yavlenij prirody, Moskva, Mysl', 522. (in Russian).

Dobrecov, A. N. (1967). Zakonomernosti razmnozhenija nestadnyh saranchovyh i prognoz ih pojavlenija v Krasnojarskom krae, Tr. Krasnojarskogo NIISH, T. 4. 168-179. (in Russian).

Fig'e, L. (1869). Zhizn' nasekomyh, Sankt-Peterburg, 546. (in Russian).

Frolov, A. N. (2011). Sovremennye napravleniya sovershenstvovaniya prognozov i monitoringa. Zashchita i karantin rastenij, №4, 15-20. (in Russian).

Golovan, L. V., Klymenko, I. V., Stankevych, S. V. (2019). The inheritance of economically valuable features in the intraspecific hybridization of bean (Phaseolus L). Ukrainian Journal of Ecology, 9 (2), 156-169.

Keppen, F. (1870). O saranche i drugih vrednyh prjamokrylyh iz sem. Acridiodea preimushhestvenno po otnosheniju k Rossii. Tr. Russk. jentomol. ob-va, T. 5, 352. (in Russian).

Knyazeva, E. N., Kurdyumov, S.P. (2002). Osnovaniya sinergetiki. Rezhimy s obostreniem, tempomiry, Sankt-Peterburg, Aletejya, 414. (in Russian).

Konakov, N. N. (1930). Istoricheskie svedenija o razmnozhenijah lugovogo motyl'ka v Central'no-Chernozemnoj oblasti. Metod. po izucheniju lugovogo motyl'ka v CChO, Voronezh, 3-38. (in Russian).

Kravchenko, V. P., CHajka, V. M. (2002). Stan populyaciï lugovogo metelika v Ukraïni. Zahist i karantin roslin: mizhvidomchij tematichnij naukovij zbirnik, Vip. 48, 17-25. (in Ukrainian).

Kripyakevich, I. (1927). Sarana na Ukraïni v HI-HVIII stolittyah. Visnik prirodoznavstva, № 3-4, 1-9. (in Ukrainian).

Kulagin, N. M. (1921). O pojavlenii saranchi v Evrope v 18-19 stoletijah. Tr. 2-go Vseross. jentomo-fitopatol. s\#ezda, Moskva, 109122. (in Russian).

Lachininskij, A. V., Gapparov, F.A., Utapov, N. (2011). Sovershenstvovanie himicheskoj bor'by s saranchovymi v Central'noj Azii. Zashchita i karantin rastenij, № 6, 5-10. (in Russian).

Letopis' Samovidca. (1878). Polnoe sobranie rus'kih letopisej. (PSRL), Kiev, 174 s. (in Russian) Lindeman I.V. (1923). Rezul'taty nablyudenij nad vazhnejshimi vreditelyami saharnoj svekly i osennih raskopok v rajone Smely Kiev. gub. V 1922 godu. Byul. SNU Sahartresta, Kiev, CHast' 7, 33. (in Russian).

Lutytska, N. V., Stankevych, S. V., Zabrodina, I. V. (2019). Soybean insect pests: A review of Ukrainian and world data. Ukrainian Journal of Ecology, 9 (3), 208-213.

Malinetskij, G. G. (1997). Sinergetika predskazuemost' i determinirovannyi khaos, Predely predskazuemosti, Moskva, Tsentr Kom, 68-130. (in Russian).

Moiseev, N. N. (2001). Universum. Informatsiia. Obshchestvo, Moskva, Ustoichivyi mir, 200. (in Russian).

Mokrzheckij, S. A. (1902). Lugovoj motylek, ego zhizn' i mery bor'by s nim. Trudy byuro po entomologii, T. 3, № 2, 36. (in Russian). Nakonechna, Yu. O., Stankevych, S. V., Zabrodina, I. V. (2019). Distribution area of Hyphantria cunea Drury: the analysis of Ukrainian and world data. Ukrainian Journal of Ecology, 9 (3), 214-220.

Nikolas, G., Prigozhin, I. (2003). Poznanie slozhnogo Vvedenie, Moskva, Editorial URSS, 344. (in Russian).

Peredel'skij, A. A. (1947). Biologicheskie osnovy teorii i praktiki bor'by s vrednoj cherepashkoj. Vrednaya cherepashka, Moskva: Izdatel's'vo ANSSSR, T. 2, 89-270. (in Russian). 
Polyakov, I. Ya. (1964). Prognoz rasprostraneniya vrediteley selsko-hozyaystvennyih kultur, Leningrad, Kolos, 326. (in Russian). Rossikov, K. N. (1903). Lugovoj motylek ili metelica (Eurycreon sticticalis L.): sel'skohozyajstvennaya monografiya, Sankt-Peterburg, 96. (in Russian).

Saharov, N. L. (1923). Entomologicheskij ocherk YUgo-Vostoka, Saratov, Nizhne-volzhskoe upravlenie po sel'skohozyajstvennomu opytnomu delu, 10. (in Russian).

Senkevich, G. (1983). Ognem i mechom, Moskva, Hudozhestvennaya Literatura, 670 s. (in Russian).

Sergeev, M. G., Lachinskij, A.V. (2007). Vrednye saranchovye: mirovoj obzor. Zashchita i karantin rastenij, №11, 24-28. (in Russian).

Sergeev, M. G. (2010). Vrednye saranchovye Rossii i sopredel'nyh regionov: proshloe, nastoyashchee, budushchee. Zashchita i karantin rastenij, №1, 18-22. (in Russian).

Stankevich, S. V., Beleckij E. N., Zabrodina, I. V. (2019). Ciklicheski-nelinejnaya dinamika prirodnyh sistem i problemy prognozirovaniya: monografiya, Vankuver, Accent Graphics Communications \& Publishing, 232. (in Russian).

Stankevych, S. V., Yevtushenko, M. D., Zabrodina, I. V. (2019). V.V. Dokuchaiev Scientific School of Kharkiv National Agrarian University and development agricultural entomology in XIX-XXI centuries. Ukrainian Journal of Ecology, 9 (2), $156-169$.

Stankevych, S. V., Vasylieva, Yu. V., Golovan, L. V., Zabrodina, I. V., Lutytska, N. V., Nakonechna, Yu. O., Molchanova, O. A., Chupryna, Yu. Yu., Zhukova, L. V. (2019). Chronicle of insect pests massive reproduction. Ukrainian Journal of Ecology, 9 (1), $262-$ 274.

Stankevych, S. V., Yevtushenko, M. D., Vilna, V. V. (2019). Integrated pest management of flea beetles (Phyllotreta spp.) in spring oilseed rape (Brassica napus L.). Ukrainian Journal of Ecology, 9 (3), 198-207.

Turenko, V. P., Bilyk, M. O., Zhukova, L. V. (2019). Pathogens of spring barley on abiotic factors in the eastern forest - steppe of Ukraine. Ukrainian Journal of Ecology, 9 (2), 179-188.

YAvornic'kij, D. I. (1990). Istoriya zaporiz'kih kozakiv, L'viv, Svit, T. 1, 500. (in Ukrainian).

Zakari, M. U., Beleckij, E. N. (1996). Zakonomernosti massovyh razmnozhenij i prognoz proyavleniya pustynnoj saranchi (Schistocerka gragaria Forsk). Sbornik nauchnyh trudov kafedry zoologi i entomologii, Har'kov, HGAU, S. 16-24. (in Russian).

Zhukova, L. V., S. V. Stankevych, V. P., Turenko. (2019). Root rots of spring barley, their harmfulness and the basic effective protection measures. Ukrainian Journal of Ecology, 9 (2), 232-238.

Zverezomb-Zubovskij, E. V. (1924). Nekotorye dannye o vreditelyah sel'skogo hozyajstva Donskoj oblasti. Trudy sel'skohozyajstvennyh Opytnyh uchrezhdenij Dona i Severnogo Kavkaza, № 174, 8. (in Russian).

\section{Citation:}

Stankevych, S. V., Baidyk, H. V., Lezhenina, I. P., Filatov, M. O., Martynenko, V.I., D'yakonov, V.I., Nepran, I. V., Mykhailenko, V. O., Havva S. V., Bondarenko, D. V., Novosad, K. B., Kava, L. P., Yakovlev, R. V., Nemerytska, L. V., Golovan, L. V., Klymenko, I. V. (2019). Wandering of mass reproduction of harmful insects within the natural habitat. Ukrainian Journal of Ecology, 9(4), 578-583.

(cc) $\mathrm{BY}_{\mathrm{Br}}$ This work is licensed under a Creative Commons Attribution 4.0. License 